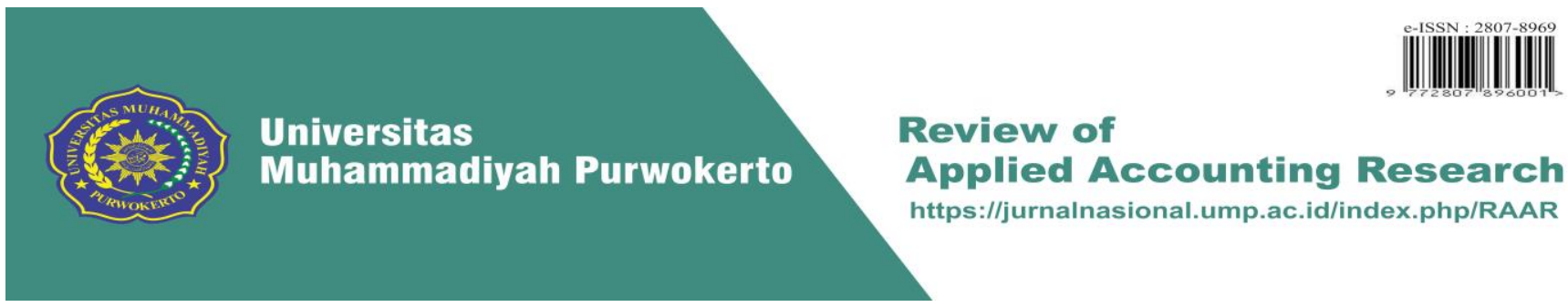

\title{
SISTEM PENGENDALIAN INTERN TERHADAP DANA RESES PADA KANTOR SEKRETARIAT DPRD BANYUMAS
}

\author{
Lufiana Sanjaya*, Iwan Fakhruddin, Novi Dirgantari
}

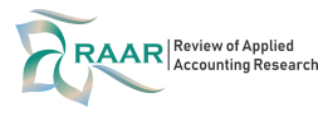

Affiliation:

Accounting Department, Universitas

Muhammadiyah Purwokerto, Indonesia

*Correspondence:

lufianasanjaya20@gmail.com

Article Process:

Submitted:

January 2, 2021

Reviewed:

January 25, 2021

Revised:

February 18, 2021

Accepted:

February 25, 2021

Published:

February 28, 2021

Citation:

Sanjaya, L., Fakhruddin, I., \& Dirgantari, N. (2021). Sistem

Pengendalian Intern Terhadap Dana

Reses Pada Kantor Sekretariat

DPRD Banyumas. Review of Applied

Accounting Research, 2(2), 37-47

Office Address:

Jl. K.H. Ahmad Dahlan,

Dukuhwaluh, Kec. Kembaran,

Kabupaten Banyumas, Jawa Tengah 53182

e-ISSN : 2807-8969

\begin{abstract}
ABSTRAK
Sistem Pengendalian Intern Dana Reses dimulai dari penetapan surat keputusan banmus, anggota dewan menyetor jumlah konstituen dan jumlah tempat penghitungan jumlah dana yang akan digunakan oleh masingmasing anggota dewan, transfer dilakukan langsung dari bagian keuangan. dinas kepada rekanan, setelah reses anggota dewan mengumpulkan berkas pertanggungjawaban, kemudian dipertanggungjawabkan pada rapat paripurna dan selanjutnya diperiksa oleh auditor Pemerintah Banyumas. Pengendalian internal dana reses di Sekretariat DPRD Banyumas telah dilaksanakan sesuai dengan ketentuan dalam surat keputusan Banmus dan juga sesuai dengan tata tertib yang berlaku di Sekretariat DPRD Banyumas. Namun pada kenyataannya masih terdapat beberapa kendala, hal ini mengakibatkan pencairan dana menjadi lebih lama atau menjadi dua kali kerja. Selain itu, ada beberapa keterlambatan dalam pengumpulan dokumen pertanggungjawaban. Flow chart atau diagram proses terkait reses sudah ada, hanya saja masih kurang jelas dan masih menimbulkan beberapa pertanyaan. Untuk itu, sebaiknya diatur ketentuan terkait reses, agar proses dan pelaksanaannya lebih teratur.
\end{abstract}

Kata Kunci: Sistem Pengendalian Intern, Dana Reses

\section{ABSTRACT}

The Recess Fund Internal Control System starts from the stipulation of the banmus decision letter, board members deposit the number of constituents and the number of places for calculating the amount of funds that will be used by each board member, transfers are made directly from the finance department to partners, after the recess the board members collect the files accountability, then accounted for at the plenary meeting and later examined by the auditors of the Banyumas Government. Internal control of recess funds at the Banyumas DPRD Secretariat has been carried out in accordance with the provisions in the Banmus decision letter and is also in accordance with the order in force at the Banyumas DPRD Secretariat. However, in reality, there are still some obstacles, this results in the disbursement of funds taking longer or making work twice. In addition, there are some delays in collecting accountability documents. The flow chart or process diagram related to the recess already exists, it's just that it's still unclear and still raises some questions. For this reason, it is better to stipulate the provisions related to recess, so that the process and implementation is more regular.

Keywords: Internal Control System, Recess Fund 


\section{PENDAHULUAN}

Dalam Pasal 1 Angka 4 UU 23 Tahun 2014 disebutkan bahwa Dewan Perwakilan Rakyat Daerah (DPRD) adalah lembaga perwakilan rakyat daerah yang berkedudukan sebagai unsur penyelenggara Pemda Kabupaten/Kota. Sebagai bagian dari Pemda tentunya DPRD Kabupaten/Kota memiliki tugas,fungsi, dan wewenang, salah satu tugasnya adalah melaksanakan kegiatan reses di masa reses. Masa reses merupakan masa dimana para anggota DPRD bekerja diluar gedung DPRD, terjun langsung dan bertemu dengan konstituen di daerah pemilihannya (Dapil) masing-masing secara rutin untuk berdiskusi dan menampung aspirasi konstituen untuk ditindaklanjuti dan dilaporkan di e-planning. Masa reses ini mengikuti masa persidangan yang dilakukan sebanyak 3 kali dalam satu tahun atau 15 kali dalam lima tahun masa jabatan anggota DPRD. Dengan adanya kegiatan reses ini, masyarakat dapat mengajukan berbagai macam aspirasi mulai dari pembangunan desa, usulan kegiatan usaha, pengadaan sarana dan prasarana dan lain-lainnya. Pada kegiatan ini juga masyarakat dapat menilai apakah anggota DPRD telah Tujuan melaksanakan tugasnya sebagai perwakilan rakyat. Karena anggota DPRD tidak hanya menjalankan fungsi perwakilan melainkanjuga memperjuangkan kepentingan-kepentingan dari rakyat yang diwakilinya.

Untuk itu sangat penting untuk dilaksanakannya kegiatan reses yang merupakan kewajiban pimpinan dan anggota DPRD dalam rangka menjaring aspirasi masyarakat secara berkala di daerah pemilihannya (Dapil) masing-masing guna meningkatkan kualitas, produktivitas, dan kinerja DPRD dalam mewujudkan keadilan dan kesejahteraan rakyat. Masih banyak masyarakat yang belum mengetahui tentang reses dan apa saja yang dilakukan oleh para anggota DPRD pada masa reses. Untuk apa dan bagaimana reses itu dilakukan masyarakat harus memahami dan mengetahuinya. Sebagai organisasi pemerintahan, DPRD Kabupaten Banyumas dalam melayani kebutuhan informasi masyarakat menggunakan jasa humas ataupun di era modern ini segala informasi bisa diakses di aplikasi ataupun di website pemerintahan. Agar masyarakat luas dapat mengetahui apa saja yang terjadi di gedung parlemen, salah satunya adalah dengan dilaksanakannya kegiatan reses.

Kegiatan reses merupakan kegiatan wajib bagi para anggota DPRD di luar masa sidang. Kewajiban ini secara spesifik juga diatur di dalam Undang- Undang Nomor 17 Tahun 2014 tentang MPR, DPR, DPD, DPRD, bahwa anggota DPRD Kabupaten diantaranya mempunyai kewajiban menyerap dan menghimpun aspirasi konstituen melalui kunjungan kerja secara berkala, menampung dan menindaklanjuti aspirasi dan pengaduan masyarakat, dan memberikan pertanggungjawaban secara moral dan politis kepada konstituen di daerah pemilihannya ( Dapil). Program masa reses ini dipergunakan oleh anggota DPRD secara perorangan ataupun kelompok untuk mengunjungi daerah pemilihannya guna menyerap aspirasi masyarakat. Kegiatan ini biasanya dilakukan selama 3 hari berturut turut, setelah melaksanakan kegiatan reses ini, anggota DPRD wajib membuat laporan tertulis atau hasil pelaksanaan tugasnya pada masa reses tersebut dan akan disampaikan kepada pimpinan DPRD dalam rapat paripurna. Biasanya laporan tertulis ini atau sering disebut spj (surat pertanggungjawaban) paling lama diproses $h+7$ hari setelah pelaksanaan kegiatan reses tersebut.

Di DPRD Kabupaten Banyumas, Reses diatur dalam peratuan DPRD Kabupaten Banyumas Nomor 1 Tahun 2018 tentang Tata Tertib DPRD Kabupaten Banyumas Bab XIII Pasal 137 yaitu bahwa setiap anggota DPRD wajib melaksanakan kegiatan aspirasi masyarakat atau reses. Pelaksanaannya yaitu 3 kali selama satu tahun dan paling lama 3 hari kerja dalam satu kali reses. Pelaksanaan kegiatan dan jadwal reses ditetapkan dalam keputusan pimpinan 
DPRD dengan pertimbangan Badan Musyawarah. Anggota DPRD Kabupaten Banyumas telah melaksanakan reses masa persidangan II tahun 2020, dengan mengacu pada Surat Keputusan Badan Musyawarah DPRD Kabupaten Banyumas Nomor 7/BANMUS/2020 tentang Jadwal Masa Persidangan II DPRD Kabupaten Banyumas Tahun Sidang 2020 bulan Februari. Bahwa jadwal kegiatan reses anggota DPRD Kabupaten Banyumas Masa Persidangan II Tahun 2020 diagendakan pada tanggal 7 s/d 9 Februari 2020. Kegiatan ini dilaksanakan di daerah pemilihannya masing-masing anggota DPRD Kabupaten Banyumas.

Dari uraian diatas penulis berkeinginan untuk membuat laporan Tugas Akhir dengan judul "SISTEM PENGENDALIAN INTERN TERHADAP DANA RESES PADA KANTOR SEKRETARIAT DPRD KABUPATEN BANYUMAS". Menurut penulis tema dan judul ini sangat perlu untuk diangkat karena kegiatan ini merupakan kegiatan yang berkaitan dengan banyak orang atau masyarakat, sehingga pengendalian internnya harus transaparan dan diketahui banyak pihak agar tidak menimbulkan banyak spekulasi negatif dari pihak luar. Berdasarkan latar belakang yang telah diuraikan diatas, maka penulis sangat ingin untuk mengetahui dan mengupas bagaimana Sistem Pengendalian Intern terhadap Dana Reses pada Kantor Sekretariat DPRD Kabupaten Banyumas.

\section{TINJAUAN PUSTAKA}

\section{Pengertian Sistem dan Pengendalian Intern}

Sistem adalah serangkaian dua atau lebih komponen yang saling terkait dan berinteraksi untuk mencapai tujuan yang sama (common purpose). Sistem terdiri dari subsistem yang mendukung sistem yang lebih besar. Setiap organisasi memiliki sistem informasi agar mempermudah jalannya kegiatan operasional. Informasi sendiri adalah data yang diolah dan diproses untuk memberikan arti dan untuk memperbaiki proses pengambilan keputusan. Sistem informasi erat hubungannya dengan penggunaan komputer, sehingga disebut sistem informasi berbasis komputer.

Pengendalian Intern adalah rencana, metode, prosedur, dan kebijakan yang di desain oleh manajemen untuk memberi jaminan yang memadai atas tercapainya efisiensi dan efektivitas operasional, kehandalan pelaporan, pengamanan terhadap aset, ketaatan/kepatuhan terhadap undang-undang, kebijakan dan peraturan lain. Banyak faktor yang mempengaruhi lingkungan pengendalian intern yaitu seperti filosofi dan gaya operasional manajemen, struktur organisasi, kebijakan operasional. Manajemen yang berlebihan menekankan target akan mempengaruhi karyawan untuk mengabaikan pengendalian. Struktur organisasi yang merupakan kerangka kerja untuk perencanaan dan pengendalian operasi sangat mempengaruhi lingkungan pengendalian. kebijakan operasional meliputi kontrak kerja, pelatihan, evaluasi, kompensasi, dan promosi atau kenaikan jabatan karyawan. Penyelenggaraan pemerintahan tentu memiliki kegiatan yang cukup banyak dan sangat luas, mulai dari perencanaan, pelaksanaan, pertanggungjawaban, pengawasan hingga evaluasi. Maka untuk mewujudkan tata kelola penyelenggaraan pemerintah yang baik tersebut pemerintah membentuk suatu sistem yang dapat mengendalikan seluruh kegiatan penyelenggaraan pemerintahan, sistem ini disebut Sistem Pengendalian Intern Pemerintahan (SPIP).

RAAR

Menurut Peraturan Pemerintah Nomor 60 Tahun 2008 tentang Sistem Pengendalian Intern Vol.1 No.1 Pemerintah adalah "Proses yang integral pada tindakan dan kegiatan yang dilakukan secara terus menerus oleh pimpinan dan seluruh pegawai untuk memberikan keyakinan memadaiatas tercapainyatujuan organisasi melalui kegiatan yang efektif dan efisien, keandalan pelaporan, 
pengamanan aset negara, dan ketaatan terhadap peraturan perundangan-undangan." Melihat pentingnya peran SPIP dalam rangka mencapai tujuan dan sasaran organisasi serta untuk mewujudkan tata kelola pemerintahan yang baik maka pimpinan instansi/organisasi harus dapat menjadikan penerapan Sistem Pengendalian Intern Pemerintahan menjadi tanggungjawab bersama tidak hanya pada unit kerja terkecil tapi hingga kepada masingmasing individu. Oleh karena itu, implementasi SPIP sangat bergantung pada komitmen, teladan pemimpin dan niat baik dari seluruh elemen dan pejabat dan pegawai instansi pemerintah.

Diagram Proses adalah cara visual untuk menjelaskan langkah- langkah atau aktivitasaktivitas dalam proses bisnis. Aktivitas DPB ditunjukkan untuk memberikan pemahaman yang lebih mudah kepada pembaca mengenai gambaran yang terjadi dalam proses bisnis. Saat DPB dapat menjelaskan interaksi dalam entitas dan juga interaksi antar- entitas, DPB dalam buku teks tidak mendokumentasikan aktivitas yang dilakukan oleh pihak eksternal. Untuk menghasilkan DPB yang mudah dibuat dan dipahami maka hanya menggunakan seperangkat simbol terbatas, yang ditunjukkan pada gambar 2.1. Simbol-simbol diagram proses beserta fungsinya, yaitu :

Tabel 1. Simbol-Simbol Diagram dan Fungsinya

\begin{tabular}{|c|c|c|c|}
\hline No. & Simbol & Nama & Penjelasan \\
\hline 1. & & Mulai & $\begin{array}{l}\text { Mulai atau permulaan proses } \\
\text { diwakili oleh lingkaran kecil. }\end{array}$ \\
\hline 2. & & Akhir & $\begin{array}{lr}\text { Akhir } & \text { proses } \\
\text { direpresentasikan } & \text { oleh } \\
\text { lingkaran kecil bergaris tebal. }\end{array}$ \\
\hline 3. & & $\begin{array}{l}\text { Aktivitas } \\
\text { dalam proses }\end{array}$ & $\begin{array}{l}\text { Aktivitas dalam proses diwakili oleh } \\
\text { persegi yang sisinya tumpul. } \\
\text { Penjelasan aktivitas ditempatkan } \\
\text { dalam persegi. }\end{array}$ \\
\hline
\end{tabular}




\begin{tabular}{|c|c|c|c|}
\hline 4. & & Keputusan & $\begin{array}{l}\text { Keputusan yang dibuat } \\
\text { selama proses diwakili oleh sebuah } \\
\text { wajik. Penjelasan keputusan } \\
\text { ditempatkan di } \\
\text { dalam simbol. }\end{array}$ \\
\hline 5. & & Arus & 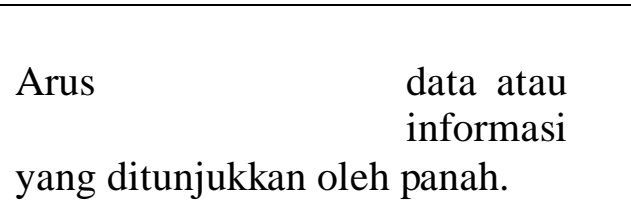 \\
\hline 6. & -- & $\begin{array}{l}\text { Informasi } \\
\text { Anotasi }\end{array}$ & $\begin{array}{l}\text { Informasi yang membantu } \\
\text { menjelaskan proses bisnis yang } \\
\text { dimasukkan ke dalam DBP dan, jika } \\
\text { dibutuhkan, panah yang tebal } \\
\text { digambar } \\
\text { dari penjelasan simbol. }\end{array}$ \\
\hline
\end{tabular}

\section{Reses}

Reses adalah masa dimana anggota DPRD nelakukan kegiatan diluar masa sidang, terutama diluar gedung DPRD, baik yang dilakukansecara perorangan ataupun secara kelompok untuk mengunjungi daerah pemilihannya (Dapil) masing-masing. Reses dilaksanakan dalam rangka untuk melaksanakan tugas dan fungsinya yaitu untuk menampung dan menyerap aspirasi dari masyarakat demi mewujudkan rasa keadilan dankesejahteran dibidang pembangunan, sosial, ekonomi dan lain-lain.

Tujuan dilaksanakannya kegiatan reses adalah untuk menjalankan tugas dan fungsinya sebagai anggota DPRD yaitu mengunjungi daerah pemilihannya (Dapil) masing-masing guna mewujudkan rasa keadilandan kesejahteraan dibidang pembangunan, pemerintahan, sosial, dan ekonomi. Selain itu, Reses juga dilaksanakan untuk menampung dan menindaklanjuti aspirasi dari masyarakat guna memberikan pertanggungjawaban moral dan politis kepada masyarakat di daerah pemilihannya sebagai perwujudan perwakilan rakyat dalam pemerintahan.

Reses dilaksanakan 3 kali dalam satu tahun selama masa jabatan. Reses dilaksanakan oleh pimpinan dan anggota DPRD tahun bersangkutan baik perorangan maupun berkelompok untuk mengunjungi daerah pemilihannya (Dapil) masing-masing. Reses dilaksanakan di daerah pemilihannya masing-masing guna untuk menjalankan tuga dan fungsinya dan juga agar masyarakat dapat menilai kinerja anggota DPRD pilihannya.

SPJ atau Surat Pertanggungjawaban Reses adalah semua dokumen yang harus dikumpulkan oleh setiap anggota DPRD yang melaksanakan reses. Dokumen ini berupa surat undangan bagi konstituen dari anggota DPRD yang bersangkutan, hasil kegiatan reses berupa risalah 
kegiatan dan ringkasan usulan dari konstituen yang hadir, fotohasil kegiatan reses, nota pembayaran makan dan minum reses, kwitansi makan dan minum reses bermaterai, kwitansi atas sewa tempat reses.

\section{Gambaran Umum Kantor Sekretariat DPRD Kabupaten Banyumas}

Kabupaten Banyumas berdiri pada tahun 1582, pada tanggal 6 April 1582 atau bertepatan dengan tanggal 12 Robiul Awal 990 Hijriyah. Kemudian ditetapkan dengan Peraturan Daerah (Perda) Kabupaten Daerah II Banyumas Nomor 2 Tahun 1990. Keberadaan sejarah Kabupaten Banyumas, dengan pendirinya yang pertama adalah Raden Joko Kaiman yang kemudian menjadi Bupati pertama, dikenal dengan julukan atau gelar Adipati Marapat ( Adipati Mrapat). Dari sejarah terungkap bahwa Raden Joko Kaiman adalah merupakan satria yang sangat luhur untuk bisa diteladani oleh segenap warga Kabupaten Banyumas khususnya karena mencerminkan : sifat altruistis yaitu tidak mementingkan dirinya sendiri, dan merupakan pejuang pembangunan yang tangguh, tanggap dan tanggon, serta pembangkit jiwa persatuan kesatuan (Majapahit, Galuh Pakuan, Pajajaran) menjadi satu daerah dan memberikan kesejahteraankepada semua saudaranya. Dengan demikian tidak salah apabila motto dan etos kerja Kabupaten Banyumas adalah Satria.

Berdasarkan Peraturan Bupati Banyumas Nomor 60 Tahun 2019 Tentang Kedudukan, Susunan Organisasi, Tugas dan Fungsi Serta Tata Kerja Sekretariat DPRD Kabupaten Banyumas. Kantor Sekretariat DPRD Kabupaten Banyumas dalam melaksanakan fungsinya memiliki Struktur Organisasi sebagai berikut :

1. Sekretaris DPRD

2. Kelompok Jabatan Fungsional

3. Kepala Bagian Umum

4. Subbag TU dan Kepegawaian

5. Subbag Rumah Tangga dan Perlengkapan

6. Subbag Humas, Protokol dan Publikasi

7. Kepala Bagian Perencanaan dan Keuangan

8. Subbag Perencanaan

9. Subbag Keuangan

10. Kepala Bagian Persidangan dan Perundang-undangan

11. Subbag Persidangan dan Risalah

12. Subbag Perundang-undangan

13. Kepala Bagian Fasilitasi Penganggaran dan Pengawasan

14. Subbag Fasilitasi Penganggaran Kerjasama dan Aspirasi

15. Subbag Fasilitasi Pengawasan

\section{HASIL}

\section{A. Sistem Pengendalian Intern Terhadap Dana Reses PadaKantor Sekretariat DPRD Kabupaten Banyumas}

\section{a. Menunggu Surat Keputusan Badan Musyawarah(BANMUS)}

Pelaksanaan reses dilakukan apabila sudah ditetapkannya surat keputusan BANMUS pada sidang paripurna. Karena pada dasarnya masa reses yaitu masa dimana anggota DPRD melaksanakan kegiatan diluar masa sidang. Jika belum ditetapkan surat keputusan BANMUS maka reses belum dapat dilaksanakan. Dalam surat keputusan BANMUS ini berisi tentang ketentuan reses, mulai dari jumlah dana yang diberikan Vol.1 No.1 untuk setiap anggota dewan sampai dengan jadwal kegiatan reses. Pelaksanaan reses 
masa sidang II berdasarkan pada Surat Keputusan Badan Musyawarah DPRD Kabupaten Banyumas No. 7/BANMUS/2020 tentang Jadwal Masa Persidangan II DPRD Kabupaten Banyumas masa sidang bulan Februari Tahun 2020 yaitu sebagai berikut :

a. Kegiatan reses anggota DPRD Kabupaten Banyumas Masa

Persidangan II Tahun 2020 diagendakan tanggal 7 s/d 9

Februari 2020

Sekretariat DPRD mengalokasikan anggaran untukkegiatan Reses Masa Persidangan II Tahun 2020 untuk 50 Anggota DPRD Kabupaten Banyumas masing-masing meliputi :

- Makanan dan Minuman Rapat (makan dan snack) untuk peserta reses/konstituen sebanyak 250 orang peserta @Rp. 37.000,- ( Snack Rp. 12.000,dan makan Rp. 25.000,-) dipotong pajak.

- Sewa gedung/ruang rapat sebanyak 4 (Empat) lokasi @Rp. 500.000,-

Sehubungan dengan hal tersebut, maka diatur pula ketentuan lainnya terkait pelaksanaan reses masa sidang II (lihat Lampiran 1).

B. Mengajukan Surat permohonan TU untuk reses ke Badan Keuangan dan Aset Daerah

Setelah ditetapkannya surat keputusan BANMUS, maka selanjutnya Bagian Fasilitasi Penganggaran, Kerjasama, dan Aspirasi membuat surat permohonan LS TU (Tambah Uang) terkait kegiatan reses yang berisi SPP-TU, Surat Pertanggungjawaban atas pengajuan SPP-TU, Surat Pertanggungjawaban Belanja, Surat Bukti Pengeluaran, Rincian (keterangan alokasi dana yang akan dilakukan) (Lihat lampiran 2-6) dan diajukan ke bendahara pengeluaran sekretariat DPRD untuk diperiksa kelengkapan dan kesesuaian anggaran yang diajukan. Jika diterima oleh bendahara pengeluaran maka selanjutnya diajukan ke Badan Keuangan dan Aset Daerah untuk diperiksa dan apabila disetujui akan diberikan surat persetujuan dari BKD dan selanjutnya melakukan proses pencairan.

\section{Melengkapi Dokumen-dokumen yang diperlukan untuk Reses}

Sebelum pelaksanaan reses, anggota DPRD diwajibkan untuk mengurus adminitrasi terkait reses. Dimana, anggota dewan diharuskan untuk menyetorkan jumlah konstituen yang akan diundang, jumlah tempat yang akan digunakan, dan menyetorkan nama dan nomor rekening rekanan. Hal ini dimaksudakan agar lebih memudahkan dalam proses pengalokasian dana untuk kegiatan reses setiap anggota dewan dan juga untuk menentukan besarnya pajak yang akan dipungut. Jika rekanan memiliki NPWP maka tarif pajaknya $2 \%$ apabila tidak memiliki NPWP maka rekanan dikenakan pajak sebesar $4 \%$. Jadi nantinya jumlah anggaran yang dialokasikan ke setiap anggota dewan sesuai dengan kebutuhan. Jika nantinya selama pelaksanaan ada perubahan jumlah konstituen, jika menambah jumlah maka mengajukan kembali dan jika mengurangi jumlah konstituen maka anggota dewan harus mengembalikan dana yang tidak terpakai. Anggaran untuk makan dan minum reses akan dikirimkan langsung ke nomor rekening rekanan setiap anggota dewan sesuai dengan permintaan anggota dewan setelah dipotong dengan pajak daerah dan pajak 23. Dan untuk anggaran untuk sewa tempat reses akan dikirimkan ke nomor rekening setiap anggotadewan 
sesuai permintaan jumlah lokasi dan setelah dipotongpajak 23 atas sewa tempat. Untuk memperjelas perhitungan.

\section{Pelaksanaan Reses}

Ketika sudah selesai mengurus adminitrasi, maka selanjutnya anggota dewan melaksanakan reses, dimana anggota dewankembali ke daerah piih nya masing-masing dan mengumpulkan konstituen untuk saling bertukar pikiran dan pengajuan beberapa aspirasi masyarakat atau konstituen. Reses dilaksanakan dalam jangka waktu 3 hari, setiap anggota dewan boleh memilih hari diantara 3 hari yang ditentukan, boleh dilaksanakan dalam satu hari maupun tiga hari penuh. Kegiatan reses dimaksudkan untuk mendekatkan dan menunjukan kerja nyata anggota dewan sebagai perwakilan rakyat yang memperjuanglan aspirasi rakyat. Untuk itu setiap ada aspirasi dari konstituen maka anggota dewan harus mencatat dan mengajukan aspirasi tersebut ke pemerintah daerah melalui E-Planning.

\section{E. Menyusun Surat Pertanggungjawaban Reses}

Setelah pelaksanaan reses selesai, maka setiap anggota dewan diwajibkan untuk menyerahkan dokumen-dokumen yang sudah ditentukan yaitu foto kegiatan reses, daftar hadir konstituen reses, kwitansi atas makan dan minum reses bermaterai 6000 dan cap/stempel rekanan, nota dari rekanan atas makan dan minum reses bertanda tangan dan stempel rekanan, kwitansi sewa tempat reses bermaterai 3000 dan berstempel, dan hasil kegiatan reses. Dokumen-dokumen tersebut digunakan untuk pertanggungjawaban setiap anggota dewan atas pelaksanaan reses. Dokumen tersebut juga digunakan untuk melaporkan pajak atas reses melalui e-billing dan untuk membuat dokumen C5 (Surat Bukti Pengeluaran). Setelah terkumpul semua dokumen maka selanjutnya bagian fasilitasi penganggaran, kerjasama dan aspirasi menyetorkan slip setoran pajak daerah dan pph 23 atas reses setiap anggota dewan kebagian keuangan, untuk selanjutnya dilakukan penyetoran pajak reses ke kas daerah. Lalu, bukti slip setoran pajak tersebut digunakan untuk kelengkapan SPJ.

\section{F. Melaporkan Surat Pertanggungjawaban pada Rapat Paripurna}

Setiap anggota dewan yang melaksanakan reses diwajibkan untuk menyampaikan pertanggungjawabannya di rapat paripurna. Hal ini berguna untuk menyampaikan tanggungjawabnya atas pelaksanaan reses, dan untuk menyampaikn aspirasi dari masyarakat. Untuk selanjutnya SPJ tersebut disepakati dan ditetapkan. Hal ini menandakan berakhirnya masa reses. 


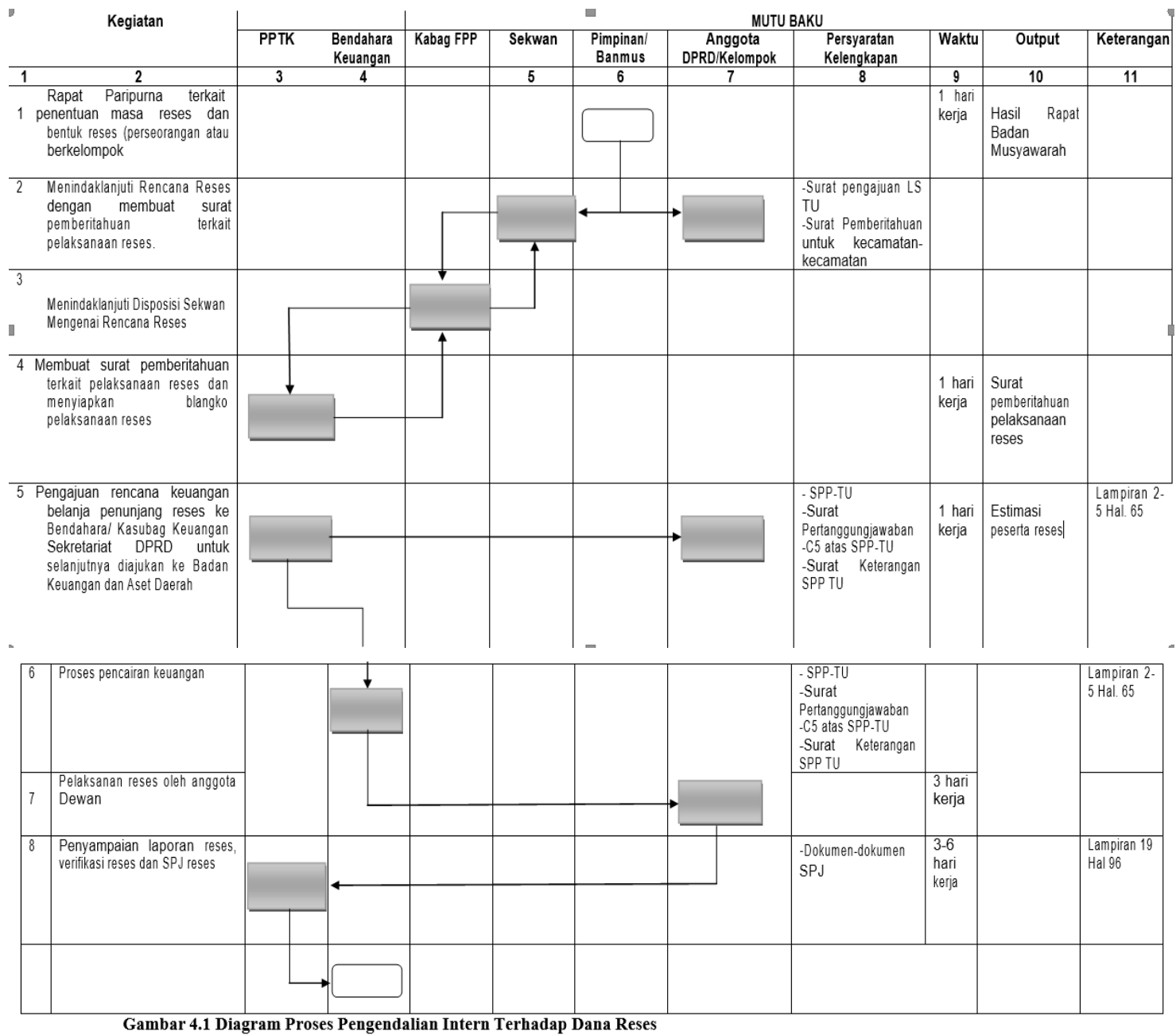

\section{B. Evaluasi Pelaksanaan}

Sistem Pengendalian Intern Terhadap Dana Reses pada Kantor DPRD Kabupaten Banyumas sudah terlaksana sesuai dengan ketentuan yang telah ditetapkan pada Surat Keputusan Banmus dan juga sesuai dengan urutan yang berlaku pada kesekretariatan DPRD yang mengelola mulai dari pengajuan anggaran sampai dengan pertanggungjawaban reses. Akan tetapi dalam keadaan yang sebenarnya dalam Kantor DPRD Kabupaten Banyumas masih terdapat beberapa kendala yaitu :

Surat Keputusan BANMUS ditetapkan saat selesai rapat paripurna sehingga waktu yang tersedia untuk persiapan sampai dengan pelaksanaan terlalu sempit, dimana surat keputusan Banmus di putuskan h-7 hari sebelum pelaksanaan atau minimal h-5 hari sebelum hari pelaksanan. Sedangkan keputusan untuk hari pelaksanaan dan ketentuan pelaksanaan reses ada pada surat keputusan Banmus. Memang sudah dari jauh jauh hari surat itu di usulkan tetapi belum ada ketetapan, sehingga belum pasti pelaksanaannya. Hal ini mengakibatkan anggota dewan hanya diberi waktu beberapa hari untuk persiapan. Belum lagi beberapa anggota dewan yang sedang melaksanakan Dinas Luar pastinya membutuhkan lebih banyak waktu untuk persiapan reses, sehingga koordinasi terkait persiapan reses tidak intens atau hanya melalui pesan atau panggilan whatsapp dan bagian fasilitasi penganggaran, kerjasama dan aspirasi yang mengurus persiapannya. 
Beberapa anggota dewan melakukan perubahan untuk jumlah konstituen ataupun jumlah lokasi reses, sehingga memerlukan waktu untuk melakukan perhitungan lagi terkait anggaran yang akan dialokasikan ke rekanan. Belum lagi jika terjadi kesalahan perhitungan (akibat human error). Oleh karena itu ada beberapa yang anggarannya dialokasikan setelah selesai pelaksanaan reses.

1. Terkait dengan SPJ, sebenarnya setiap anggota dewan hanya diberi waktu 7 hari untuk mengumpulkan dokumen spj, tetapi tak jarang anggota dewan masih melebihi batas waktu yang ditentukan, entah itu karena dokumen yang belum lengkap ataupun yang sama sekali belum ada waktu untuk menyerahkan dokumen spj.

2. Pada kantor DPRD Kabupaten Banyumas sudah terdapat diagram proses maupun bagan alir yang memudahkan setiap anggota dewan memahami tahapan pelaksanaan reses. Tetapi aliran dalam setiap proses pada setiap aktivitas masih belum terlalu jelas dan masih menimbulkan banyak pertanyaan.

3. Pada Kantor Sekretariat DPRD Banyumas belum dibuatkan Buku Kas Pembantu Pajak untuk setiap kegiatan, seperti untuk kegiatan reses. Padahal buku pajak ini sangat membantu dalam mencatat semua transaksi yang berkaitan dengan pajak, baik itu sebagai pemungut ataupun yang dipungut. Juga sebagai bentuk pengendalian, agar lebih relevan data dan pertanggungjawaban.

4. Untuk proses pengajuan LS TU belum terdapat SPM (Surat Perintah Membayar). Surat Perintah Membayar ini seharusnya diterbitkan ketika adanya pengajuan Tambah Uang oleh pengguna anggaran.

\section{Evaluasi Pelaksanaan}

Sistem Pengendalian Intern Terhadap Dana Reses pada Kantor DPRD Kabupaten Banyumas sudah terlaksana sesuai dengan ketentuan yang telah ditetapkan pada Surat Keputusan Banmus dan juga sesuai dengan urutan yang berlaku pada kesekretariatan DPRD yang mengelola mulai dari pengajuan anggaran sampai dengan pertanggungjawaban reses. Akan tetapi dalam keadaan yang sebenarnya dalam Kantor DPRD Kabupaten Banyumas masih terdapat beberapa kendala yaitu :

Surat Keputusan BANMUS ditetapkan saat selesai rapat paripurna sehingga waktu yang tersedia untuk persiapan sampai dengan pelaksanaan terlalu sempit, dimana surat keputusan Banmus di putuskan h-7 hari sebelum pelaksanaan atau minimal h-5 hari sebelum hari pelaksanan. Sedangkan keputusan untuk hari pelaksanaan dan ketentuan pelaksanaan reses ada pada surat keputusan Banmus. Memang sudah dari jauh jauh hari surat itu di usulkan tetapi belum ada ketetapan, sehingga belum pasti pelaksanaannya. Hal ini mengakibatkan anggota dewan hanya diberi waktu beberapa hari untuk persiapan. Belum lagi beberapa anggota dewan yang sedang melaksanakan Dinas Luar pastinya membutuhkan lebih banyak waktu untuk persiapan reses, sehingga koordinasi terkait persiapan reses tidak intens atau hanya melalui pesan atau panggilan whatsapp dan bagian fasilitasi penganggaran, kerjasama dan aspirasi yang mengurus persiapannya.

Beberapa anggota dewan melakukan perubahan untuk jumlah konstituen ataupun jumlah lokasi reses, sehingga memerlukan waktu untuk melakukan perhitungan lagi terkait anggaran yang akan dialokasikan ke rekanan. Belum lagi jika terjadi kesalahan perhitungan (akibat human error). Oleh karena itu ada beberapa yang anggarannya Vol.1 No.1 dialokasikan setelah selesai pelaksanaan reses. 
5. Terkait dengan SPJ, sebenarnya setiap anggota dewan hanya diberi waktu 7 hari untuk mengumpulkan dokumen spj, tetapi tak jarang anggota dewan masih melebihi batas waktu yang ditentukan, entah itu karena dokumen yang belum lengkap ataupun yang sama sekali belum ada waktu untuk menyerahkan dokumen spj.

6. Pada kantor DPRD Kabupaten Banyumas sudah terdapat diagram proses maupun bagan alir yang memudahkan setiap anggota dewan memahami tahapan pelaksanaan reses. Tetapi aliran dalam setiap proses pada setiap aktivitas masih belum terlalu jelas dan masih menimbulkan banyak pertanyaan.

7. Pada Kantor Sekretariat DPRD Banyumas belum dibuatkan Buku Kas Pembantu Pajak untuk setiap kegiatan, seperti untuk kegiatan reses. Padahal buku pajak ini sangat membantu dalam mencatat semua transaksi yang berkaitan dengan pajak, baik itu sebagai pemungut ataupun yang dipungut. Juga sebagai bentuk pengendalian, agar lebih relevan data dan pertanggungjawaban.

8. Untuk proses pengajuan LS TU belum terdapat SPM (Surat Perintah Membayar). Surat Perintah Membayar ini seharusnya diterbitkan ketika adanya pengajuan Tambah Uang oleh pengguna anggaran.

1. pada buku kas pembantu pajak.

2. Dalam pengajuan LS TU sebaiknya diterbitkan juga Surat Perintah Membayar (SPM) agar lebih lengkap dan lebih sesuai dengan ketentuan administrasi pengajuan dana kepada Badan Keuangan dan Aset Daerah.

\section{REFERENSI}

Surat Pemberitahuan Keputusan BANMUS No 7/BANMUS/2020 tentang Jadwal Masa Persidangan II DPRD Kabupaten Banyumas masa sidang Bulan Februari Tahun 2020.

Setwan Banyumas. Perda No 3 2019. https://setwan.banyumaskab.go.id. Diakses pada 2 April 2020

Setwan Banyumas. Perda No 1 2019. https://setwan.banyumaskab.go.id. Diakses pada 2 April 2020

Banyumaskab. STOK SETWAN. www.banyumaskab.go.id. Diakses pada 7 April 2020 Banyumaskab. Sejarah Singkat Kabupaten Banyumas. www.banyumaskab.go.id. Diakses pada 7 April 2020

Romney Marshall dan Paul John Steinbart. 2015. Sistem Informasi Akuntansi. Jakarta Selatan : Salemba Empat.

DJPOnline-Pajak.Mengisi E-Billing. https://djponline.pajak.go.id. Diakses pada 13 Februari 2020 dan 10 Juni 2020

Satria Banyumaskab.Membuat C5. https://satria.banyumaskab.go.id/2020/. Diakses pada 31 Januari 2020 dan 26 Mei 2020

Satria Banyumaskab. Menginput NTPN. https://satria.banyumaskab.go.id/2020/. Diakses 